\title{
The digestive capacity of the caecum-colon and the value of the nitrogen absorbed from the hind gut for protein synthesis in pigs
}

\author{
BY A. JUST, H. JØRGENSEN AND J. A. FERNÁNDEZ \\ The National Institute of Animal Science, Rolighedsvej 25, 1958 Copenhagen V., \\ Denmark
}

(Received 13 October 1980 - Accepted 18 March 198I)

\begin{abstract}
1. The aim of the investigation was to study the effects of lysine, methionine, crude protein, a complete balanced diet, maize starch and potato starch infused continuously into the caecum on the digestibilty of the nutrients, urinary nitrogen excretion and $\mathrm{N}$ balance in the presence of a normal or a depressed (modified) microflora.

2. The effects of the infused nutrients on digestibility differed when diets supplemented with antibiotics were compared with unsupplementeci diets.

3. Infused lysine improved the digestibility of crude protein (0.004/g lysine), crude fibre (0.01/g lysine), gross energy $(0.003 / \mathrm{g}$ lysine $)$ and lysine $(0.03 / \mathrm{g}$ lysine) when the diets were not supplemented with antibiotics.

4. Infused lysine, methionine and crude protein seemed to be of very little value for protein synthesis in the pigs, as the effects on $\mathrm{N}$ balance, although positive, were very small.

5. Despite the fact that a pari of the infused lysine passed through the caecum-colon and into the faeces intact, the effect on $\mathbf{N}$ balance was negligible, indicating that the ability to absorb amino acids through the gut wall in the caecum-colon was very poor.

6. Crude protein, a complete balanced diet, maize starch and potato starch infused into the caecum were digested almost as well as if they had beer given orally, thus demonstrating the large digestive capacity of the caecum-colon.
\end{abstract}

Numerous investigations have shown that the apparent digestibility of crude protein and amino acids may be influenced by the microflora present in the alimentary canal and by diet composition. Among others, Combe et al. (1965) and Salter \& Coates $(1970,1971)$ found a higher content of urea in the caecum and in faeces and a larger nitrogen excretion in faeces from germ-free animals than in conventional animals. However, Salter et al. (1974) did not find any difference in net protein utilization between germ-free and conventional chicks. Dammers (1964), Eggum (1972), Zebrowska \& Pastuszewska (1975), Mason et al. (1976), Eggum et al. (1979) and Just, Sauer, Bech-Andersen et al. (1980) showed that addition of antibiotics to the diets can alter the apparent digestibility of protein and amino acids by $0.03-0.05$.

Mason et al. (1976), Livingstone et al. (1977), Sauer et al. (1980), Just, Sauer \& Jørgensen (1980) and Just (1980a) have shown that dietary composition, particularly the source and treatment of starch, influences the apparent digestibility of the nitrogenous compounds and the amounts disappearing from the hind gut. Zebrowska (1973) found that $N$ from casein given orally or infused into the duodenum was retained in similar proportions. However, Zebrowska (1975), Zebrow'ska \& Pastuszewska (1975), Sauer (1976), Hodgon (1977) and Zebrowska et al. (1977) have shown that protein or amino acids infused discontinuously into the caceum have little or no protein value as the $\mathrm{N}$ was almost entirely excreted in the urine.

The aim of the present study was to elucidate in more detail the digestive capacity of the caecum-colon in the presence of the normal or a depressed (modified) microflora and the value of the nutrients absorbed in this region. The present paper mainly deals with the digestibility and utilization of crude protein $(\mathrm{N} \times 6.25)$ and the more important amino acids. The results concerning fatty acids and utilization of energy will be published elsewhere. 
A. Just, H. Jørgensen and J. A. Fernández

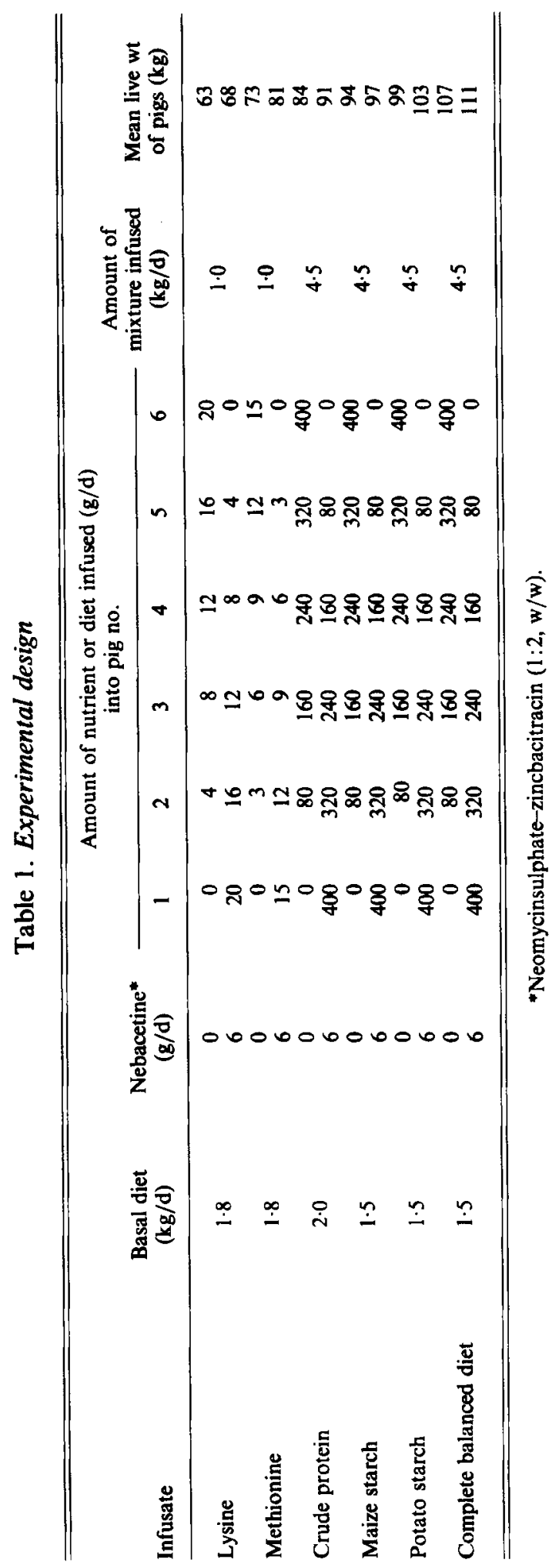


Table 2. C'hemical composition $(\mathrm{g} / \mathrm{kg})$ of diets and infusates

\begin{tabular}{|c|c|c|c|c|c|c|}
\hline $\begin{array}{l}\text { Infusate... } \\
\text { Composition of diet* }\end{array}$ & Lysine & Methionine & $\begin{array}{l}\text { Crude } \\
\text { protein }\end{array}$ & $\begin{array}{l}\text { Maize } \\
\text { starch }\end{array}$ & $\begin{array}{l}\text { Potato } \\
\text { starch }\end{array}$ & $\begin{array}{c}\text { Complete } \\
\text { balanced } \\
\text { diet }\end{array}$ \\
\hline Barley & & & 150 & 733 & 733 & 530 \\
\hline Oats & & & 337 & 100 & 100 & \\
\hline Maize & 97 & & & & & \\
\hline Maniok meal & & 290 & 150 & & & 150 \\
\hline Potato starch & 245 & 100 & 150 & & & \\
\hline Maize starch & 245 & 100 & 150 & & & \\
\hline Sugar & 30 & 30 & 30 & & & \\
\hline Sugar-beet molasses & & & & & & 30 \\
\hline Animal fat & 10 & 10 & & & & \\
\hline Soya-bean meal & & & & 103 & 103 & 230 \\
\hline Blood meal & & 150 & & & & \\
\hline Maize-gluten meal & 240 & & & & & \\
\hline Whey powder & & 125 & & & & \\
\hline Meat-and-bone meal & & 55 & & 50 & 50 & \\
\hline Barley straw (ammonia-treated) & 97 & & & & & \\
\hline Sugar-beet waste & & 120 & & & & \\
\hline Citrus pulp & & & & & & 30 \\
\hline \multicolumn{7}{|l|}{ Infusate } \\
\hline Maize starch & & & & 1000 & & 403 \\
\hline Potato starch & & & & & 1000 & 282 \\
\hline Soya-bean meal & & & 800 & & & \\
\hline Soya-bean-protein concentrate & & & & & & 160 \\
\hline Skim milk powder & & & 100 & & & 50 \\
\hline Meat-and-bone meal & & & 100 & & & 20 \\
\hline Lysine hydrochloride & 1000 & & & & & \\
\hline DL-methionine & & 1000 & & & & \\
\hline Cellulose & & & & & & 57 \\
\hline
\end{tabular}

* Mineral and vitamin pre-mix were added to meet Danish Standards (Andersen \& Just. 1979).

MATERIALS AND METHODS

Experimental design

Five different diets and six different infusion mixtures (Tables 1, 2) were used. Two trials were performed with each diet and infusion mixture. In one trial antibiotics (Nebacetine) were added to diets; in the other trial antibiotics were omitted. Six Danish Landrace female pigs (litter mates) were usec in each trial and were fitted with simple caecal cannulas placed opposite to the ostium ileo caecocollicum and slightly towards the apex caeci. One pig was infused with water only whie the other five pigs were infused with the mixtures. The nutrient concentration in the mixture was increased linearly from pig no. 2 to pig no. 6 .

It was attempted to perform all trials with the same six pigs, but reserve pigs were available (half sisters) and one of them was used.

The pigs fed antibiotics were given $6 \mathrm{~g} / \mathrm{d}$, which is several times the dose that would be recommended for therapeuic purposes. The possibility of carry-over effects caused by the addition of antibiotics from one experiment to another is very limited as the zincbacitracin is not absorbable; neomycinsulphate may be absorbed but only to a limited extent and there was always at least a week between the experimental periods. However, direct experimental evidence is lacking. 
A. Just, H. Jørgensen ANd J. A. Fernández

Table 3. Chemical composition of dry matter (DM; $\mathrm{g} / \mathrm{kg}$ ) in basal diets and infusates

\begin{tabular}{|c|c|c|c|c|c|c|}
\hline $\begin{array}{l}\text { Trial no. ... } \\
\text { Results shown in Table... } \\
\text { Infusate... } \\
\quad \text { Basal diet }\end{array}$ & $\begin{array}{l}1 \\
4 \\
\text { Lysine }\end{array}$ & $\begin{array}{l}2 \\
5 \\
\text { Methionine }\end{array}$ & $\begin{array}{l}3 \\
6 \\
\text { Crude } \\
\text { protein }\end{array}$ & $\begin{array}{l}4 \\
7 \\
\text { Maize } \\
\text { starch }\end{array}$ & $\begin{array}{l}5 \\
8 \\
\text { Potato } \\
\text { starch }\end{array}$ & $\begin{array}{l}6 \\
9 \\
\text { Complete } \\
\text { balanced } \\
\text { diet }\end{array}$ \\
\hline $\begin{array}{l}\text { DM }(\mathrm{g} / \mathrm{kg} \text { diet) } \\
\text { Crude protein* } \\
\text { Crude fat } \\
\text { Crude fibre } \\
\text { NFE } \dagger \\
\text { Soluble carbohydrates } \\
\text { Gross energy (MJ) }\end{array}$ & $\begin{array}{l}892 \\
209 \\
35 \\
45 \\
653 \\
578 \\
17 \cdot 87\end{array}$ & $\begin{array}{l}908 \\
219 \\
30 \\
48 \\
626 \\
492 \\
17 \cdot 71\end{array}$ & $\begin{array}{l}883 \\
78 \\
27 \\
45 \\
798 \\
711 \\
17 \cdot 17\end{array}$ & $\begin{array}{l}878 \\
195 \\
39 \\
48 \\
656 \\
521 \\
18 \cdot 14\end{array}$ & $\begin{array}{l}871 \\
193 \\
36 \\
51 \\
658 \\
515 \\
18 \cdot 14\end{array}$ & $\begin{array}{l}872 \\
193 \\
29 \\
59 \\
653 \\
509 \\
17.89\end{array}$ \\
\hline $\begin{array}{l}\text { Lysine } \\
\text { Methionine } \\
\text { Cystine } \\
\text { Threonine } \\
\text { Isoleucine } \\
\text { Leucine } \\
\text { Tryptophan } \\
\text { Valine } \\
\text { Phenylalanine } \\
\text { Tyrosine } \\
\text { Histidine } \\
\text { Aspartic acid } \\
\text { Serine } \\
\text { Glutamic acid } \\
\text { Proline } \\
\text { Glycine } \\
\text { Alanine } \\
\text { Arginine }\end{array}$ & $\begin{array}{l}4 \cdot 0 \\
4 \cdot 7 \\
3 \cdot 5 \\
6.9\end{array}$ & $\begin{array}{l}16 \cdot 7 \\
2 \cdot 6 \\
2 \cdot 3 \\
8 \cdot 9\end{array}$ & $\begin{array}{r}2.9 \\
1.4 \\
1.8 \\
2.6 \\
2.9 \\
5 \cdot 7 \\
0 \cdot 7 \\
4 \cdot 0 \\
3 \cdot 7 \\
2 \cdot 6 \\
1.6 \\
5 \cdot 6 \\
3 \cdot 3 \\
16 \cdot 5 \\
5 \cdot 2 \\
3 \cdot 5 \\
3.5 \\
4.7\end{array}$ & $\begin{array}{r}8 \cdot 4 \\
3 \cdot 2 \\
3 \cdot 4 \\
6 \cdot 8 \\
7 \cdot 3 \\
13 \cdot 8 \\
2 \cdot 1 \\
9 \cdot 4 \\
9 \cdot 3 \\
6 \cdot 4 \\
3.8 \\
15 \cdot 0 \\
8 \cdot 7 \\
42 \cdot 2 \\
16 \cdot 9 \\
10 \cdot 8 \\
9.0 \\
11.8\end{array}$ & $\begin{array}{r}8.4 \\
3.1 \\
3.5 \\
6.7 \\
7 \cdot 1 \\
13.6 \\
2.1 \\
9.4 \\
8.9 \\
5.9 \\
4.3 \\
15.0 \\
8.8 \\
4.2 \\
17 \cdot 1 \\
11.0 \\
9.1 \\
11.9\end{array}$ & $\begin{array}{r}9 \cdot 5 \\
3 \cdot 1 \\
3 \cdot 0 \\
7 \cdot 1 \\
7 \cdot 7 \\
14 \cdot 2 \\
2 \cdot 3 \\
9 \cdot 3 \\
9 \cdot 4 \\
6 \cdot 4 \\
4 \cdot 6 \\
17 \cdot 8 \\
9 \cdot 3 \\
41 \cdot 7 \\
14 \cdot 3 \\
8 \cdot 5 \\
8 \cdot 3 \\
12 \cdot 3\end{array}$ \\
\hline $\begin{array}{l}\quad \text { Infusate } \\
\text { DM (g/kg infusate) } \\
\text { Crude protein* } \\
\text { Crude fat } \\
\text { Crude fibre } \\
\text { NFE† } \\
\text { Soluble carbohydrates } \\
\text { Gross energy (MJ) }\end{array}$ & 970 & 1000 & $\begin{array}{l}927 \\
635 \\
10 \\
30 \\
230 \\
98 \\
19 \cdot 27\end{array}$ & $\begin{array}{c}874 \\
1 \\
6 \\
1 \\
992 \\
968 \\
17 \cdot 28\end{array}$ & $\begin{array}{c}819 \\
1 \\
0 \\
4 \\
991 \\
993 \\
17 \cdot 24\end{array}$ & $\begin{array}{l}868 \\
146 \\
5 \\
60 \\
743 \\
700 \\
17 \cdot 27\end{array}$ \\
\hline $\begin{array}{l}\text { Lysine } \\
\text { Methionine } \\
\text { Cystine } \\
\text { Threonine } \\
\text { Isoleucine } \\
\text { Leucine } \\
\text { Tryptophan } \\
\text { Valine } \\
\text { Phenylalanine } \\
\text { Tyrosine } \\
\text { Histidine } \\
\text { Aspartic acid } \\
\text { Serine } \\
\text { Glutamic acid } \\
\text { Proline } \\
\text { Glycine } \\
\text { Alanine } \\
\text { Arginine }\end{array}$ & $800 \cdot 0$ & 994.0 & $\begin{array}{r}40 \cdot 3 \\
9.4 \\
7.9 \\
24.9 \\
30.6 \\
51.8 \\
8.3 \\
32.7 \\
30 \cdot 4 \\
22.8 \\
16 \cdot 1 \\
67.9 \\
30.6 \\
119.0 \\
38.2 \\
31 \cdot 0 \\
28.7 \\
45 \cdot 1\end{array}$ & & & $\begin{array}{r}9 \cdot 2 \\
2 \cdot 4 \\
1.8 \\
5 \cdot 6 \\
6.5 \\
11 \cdot 7 \\
1.6 \\
7 \cdot 4 \\
6.9 \\
4.9 \\
3.7 \\
15 \cdot 6 \\
7 \cdot 3 \\
28 \cdot 3 \\
9.1 \\
6 \cdot 8 \\
6.5 \\
9.9\end{array}$ \\
\hline
\end{tabular}

$* \mathrm{~N} \times 6.25$.

+ NFE, nitrogen-free extract. 


\section{Diets}

The diets (Tables 2,3) used in the trials with lysine, methionine and protein were based on a large number of foodstuffs and were designed to be deficient in the nutrient to be infused although balanced with regard to all other nutrients. Thus, the amounts of lysine, methionine and crude protein were $4 \cdot 0,2.6$ and $78 \mathrm{~g} / \mathrm{kg}$ dietary dry matter (DM) respectively. Meat-and-bone meal $(50 \mathrm{~g} / \mathrm{kg} \mathrm{diet})$ and oats $(100 \mathrm{~g} / \mathrm{kg}$ diet $)$ were included in the diets fed during maize and raw potato starch infusions in order to ensure sufficient amounts of nutrients for the fermentation processes in the hind gut. All diets were ground through a $4 \mathrm{~mm}$ screen.

The meat-and-bone meal used in the infusion mixtures was sieved through a $1 \mathrm{~mm}$ screen in order to remove bristles. pieces of bone etc. and was then ground through a $0.5 \mathrm{~mm}$ screen.

\section{Analytical methods}

The chemical analyses were performed according to procedures described by Jakobsen \& Weidner (1973). DM in the foodstuffs was determined by drying in a drying kiln at $100^{\circ}$. $\mathbf{N}$ was analysed according to the $\mathrm{Kjeldahl}$ method. Crude fat (Stoldt fat) was determined by hydrolysis with hydrochloric acid followed by diethyl ether extraction. Crude fibre was defined as the insoluble fraction after boiling with sulphuric acid $(50 \mathrm{ml} / \mathrm{l})$ for $30 \mathrm{~min}$ followed by boiling witt. potassium hydroxide for $30 \mathrm{~min}$. Amino acid analyses were performed using a Durrum D 500 amino acid analyser. The procedures used were those described by Weidner \& Eggum (1966), Eggum (1968) and Bech-Andersen (1979). $N$ in faeces was determined in undried samples. All other analyses of faeces were performed on freeze dried samples.

\section{Infusion and collection procedures}

The pigs were kept in metabolism cages and were given equal amounts of the diets at three times daily (Table 1). Each trial consisted of a $5 \mathrm{~d}$ adaptation period and a $7 \mathrm{~d}$ collection period. Urine was collected by using balloon catheters inserted into the urine bladder and sulphuric acid was added to the collection containers.

Faeces and urine were collected twice and once daily respectively, and stored in air-tight bottles at $4^{\circ}$. At the end of the trial the faeces were ground and mixed and samples were taken for analysis. The solutions (lysine $\&$ methionine) for infusion were prepared once daily and the suspensions were prepared twice daily.

The nutrients for infusion were mixed with distilled water in 51 glass bottles. The contents of the bottles were stirred continuously, using magnetic stirrers, throughout the $12 \mathrm{~d}$ infusion period. The bottles and their contents were weighed and samples were taken for analysis at the beginning and end of the collection period. The caecal infusions were performed using a Colori Peristaltic Pump 3610 (Colora Messtechnik GMBH, Lorch/ Württemberg, West Germany).

\section{Statistical procedures}

All values were subjected to regression analysis and analysis of variance using the SAS system of Barr et al. (1979). The lack of replication makes it necessary to assume that there is no interaction between the addition of antiobiotics and the infusion mixture when testing the significance of the antibiotics effect.

\section{RESULTS}

There were few technical problems with the infusion although the tube broke in one instance (water only) and tubes beisame blocked occasionally. According to the manufacturer, the accuracy of the infusion pump should be \pm 0.033 , but the pooled standard deviation amounted to \pm 0.088 , which could be due partly to the occurrence of blockages. 
Table 4. The influence of infused lysine on the digestibility of nutrients and nitrogen balance

\begin{tabular}{|c|c|c|c|c|c|c|}
\hline & \multirow[b]{2}{*}{ Antibiotics } & \multirow[b]{2}{*}{ Mean } & \multirow[b]{2}{*}{ SEM } & \multicolumn{3}{|c|}{$\begin{array}{l}\text { Regression of nutrient digestibility } \\
\text { and } N \text { balance } v \cdot g \text { lysine infused }\end{array}$} \\
\hline & & & & $b$ & $t^{*}$ & $r^{2}$ \\
\hline \multirow[t]{2}{*}{ Crude protein $(\mathrm{N} \times 6.25)$} & - & $0 \cdot 837$ & 0.012 & $0.40 \dagger$ & $6 \cdot 3$ & 0.93 \\
\hline & + & 0.866 & 0.010 & $-0.37 \dagger$ & $3 \cdot 1$ & 0.70 \\
\hline \multirow{2}{*}{ Crude fat } & - & 0.623 & 0.004 & $-0.02 \dagger$ & 0.3 & 0.03 \\
\hline & + & 0.717 & 0.009 & $-0.21+$ & $1 \cdot 3$ & 0.30 \\
\hline \multirow{2}{*}{ Crude fibre } & - & $0 \cdot 102$ & 0.043 & $1.24 \dagger$ & $2 \cdot 7$ & 0.71 \\
\hline & + & 0.020 & 0.032 & $-0-20 \dagger$ & $0 \cdot 3$ & 0.02 \\
\hline \multirow[t]{2}{*}{ Gross energy } & - & 0.825 & $0.009^{\circ}$ & $0.26 \dagger$ & $3 \cdot 2$ & 0.78 \\
\hline & + & 0.766 & 0.004 & $-0.01 \dagger$ & $0 \cdot 2$ & 0.01 \\
\hline \multirow[t]{2}{*}{ Urinary $N(g / d)$} & - & $36 \cdot 7$ & $2 \cdot 3$ & 0.30 & 0.7 & 0.15 \\
\hline & + & 38.4 & 0.6 & -0.15 & 1.4 & 0.34 \\
\hline \multirow[t]{2}{*}{$N$ balance $(g / d)$} & - & $9 \cdot 4$ & $2 \cdot 0$ & 0.06 & 0.1 & 0.01 \\
\hline & + & $9 \cdot 2$ & 0.6 & 0.09 & 0.8 & 0.13 \\
\hline \multirow[t]{2}{*}{ Lysine } & - & 0.754 & 0.082 & $2.63 \dagger$ & $4 \cdot 7$ & 0.88 \\
\hline & + & 0.795 & 0.047 & $-0.70 \dagger$ & 0.8 & 0.13 \\
\hline \multirow[t]{2}{*}{ Lysine $(\mathrm{g} / \mathrm{d})$} & - & 11.8 & $3 \cdot 2$ & 1.08 & $69 \cdot 1$ & 1.00 \\
\hline & + & 11.0 & 1.7 & 0.63 & $3 \cdot 5$ & 0.75 \\
\hline
\end{tabular}

* Significance of regression coefficient: $P<0.05$ if $t>2.78, P<0.01$ if $t>4.60, P<0.001$ if $t>8.61$.

$+b \times 100$.

Table 5. The influence of infused methionine on the digestibility of nutrients and nitrogen balance

\begin{tabular}{|c|c|c|c|c|c|c|}
\hline & \multirow[b]{2}{*}{ Antibiotics } & \multirow[b]{2}{*}{ Mean } & \multirow[b]{2}{*}{ SEM } & \multicolumn{3}{|c|}{$\begin{array}{l}\text { Regression of nutrient digestibility } \\
\text { and } \mathrm{N} \text { balance } v . \mathrm{g} \text { methionine infused }\end{array}$} \\
\hline & & & & $b$ & $t^{*}$ & $r^{2}$ \\
\hline \multirow[t]{2}{*}{ Crude protein $(\mathrm{N} \times 6.25)$} & - & 0.747 & 0.011 & $0 \cdot 22 \dagger$ & $1 \cdot 2$ & 0.27 \\
\hline & + & 0.753 & 0.009 & $-0.02 \dagger$ & $0 \cdot 2$ & 0.01 \\
\hline \multirow[t]{2}{*}{ Crude fat } & - & 0.663 & 0.007 & $0.07 \dagger$ & 0.6 & 0.08 \\
\hline & + & 0.724 & 0.014 & $0.19 \dagger$ & 0.8 & $0 \cdot 14$ \\
\hline \multirow[t]{2}{*}{ Crude fibre } & - & 0.671 & 0.007 & $0.03 t$ & 0.3 & 0.02 \\
\hline & + & 0.192 & 0.040 & $1 \cdot 02 \dagger$ & 1.7 & 0.42 \\
\hline \multirow[t]{2}{*}{ Gross energy } & - & 0.859 & 0.004 & $0.06+$ & 0.8 & $0 \cdot 14$ \\
\hline & + & 0.811 & 0.006 & $0.21 \dagger$ & 3.5 & 0.75 \\
\hline \multirow[t]{2}{*}{ Urinary $N(g / d)$} & - & $23 \cdot 4$ & $1 \cdot 1$ & $0 \cdot 22$ & $1 \cdot 2$ & 0.28 \\
\hline & + & $24-8$ & 1.4 & 0.02 & 0.1 & 0.00 \\
\hline \multirow[t]{2}{*}{$N$ balance $(g / d)$} & - & $20 \cdot 3$ & $1 \cdot 3$ & 0.03 & $0 \cdot 1$ & 0.00 \\
\hline & + & $19 \cdot 4$ & $1 \cdot 3$ & 0.09 & 0.4 & 0.03 \\
\hline \multirow[t]{2}{*}{ Methionine } & - & 0.883 & 0.033 & $1.07 \dagger$ & $3 \cdot 1$ & 0.71 \\
\hline & + & 0.860 & 0.026 & $0.08+$ & 0.2 & 0.01 \\
\hline \multirow[t]{2}{*}{ Methionine $(\mathrm{g} / \mathrm{d})$} & - & $11 \cdot 2$ & 2.6 & 1.00 & 90.6 & 1.00 \\
\hline & + & $10 \cdot 8$ & $2 \cdot 2$ & 0.84 & 12.7 & 0.98 \\
\hline \multirow{2}{*}{ Cystine } & - & 0.706 & 0.012 & $0 \cdot 18+$ & 0.8 & 0.14 \\
\hline & + & 0.720 & 0.009 & $0-22 \dagger$ & 1.7 & 0.41 \\
\hline
\end{tabular}

* Significance of regression coefficient: $P<0.05$ if $t>2.78, P<0.01$ if $t>4.60, P<0.001$ if $t>8.61$.

$\dagger b \times 100$. 
Table 6. The influence of infused crude protein on the digestibility of nutrients and nitrogen balance

\begin{tabular}{|c|c|c|c|c|c|c|}
\hline & \multirow[b]{2}{*}{ Antibiotics } & \multirow[b]{2}{*}{ Mean } & \multirow[b]{2}{*}{ SEM } & \multicolumn{3}{|c|}{$\begin{array}{l}\text { Regression of nutrient digestibility } \\
\text { and } \mathrm{N} \text { balance } v . \mathrm{g} \text { crude protein infused }\end{array}$} \\
\hline & & & & $b$ & $t^{*}$ & $r^{2}$ \\
\hline \multirow[t]{2}{*}{ Crude protein $(\mathrm{N} \times 6.25)$} & - & 0.733 & 0.013 & $0.02 \dagger$ & $1 \cdot 1$ & 0.24 \\
\hline & + & 0.794 & 0.008 & $0.01+$ & 0.8 & 0.14 \\
\hline \multirow{2}{*}{ Crude fat } & - & 0.555 & 0.017 & $-0.02 \dagger$ & 0.8 & 0.13 \\
\hline & + & 0.592 & 0.017 & $0.03 t$ & $1 \cdot 3$ & 0.29 \\
\hline \multirow[t]{2}{*}{ Crude fibre } & - & 0.034 & 0.038 & $0.00 \dagger$ & $0 \cdot 1$ & 0.00 \\
\hline & + & 0.029 & 0.029 & $0.06 \dagger$ & $1 \cdot 6$ & 0.38 \\
\hline \multirow[t]{2}{*}{ Gross energy } & - & 0.806 & 0.004 & $-0.01 \dagger$ & 0.9 & 0.15 \\
\hline & + & 0.805 & 0.007 & $0.00 \dagger$ & $0 \cdot 3$ & 0.02 \\
\hline \multirow[t]{2}{*}{ Urinary $N(g / d)$} & - & $23 \cdot 1$ & $3 \cdot 2$ & $0 \cdot 11$ & $4 \cdot 5$ & 0.83 \\
\hline & + & $27 \cdot 7$ & $4 \cdot 4$ & 0.15 & $16 \cdot 8$ & 0.99 \\
\hline \multirow{2}{*}{$N$ balance $(g / d)$} & - & $4 \cdot 5$ & $1 \cdot 2$ & 0.02 & $1 \cdot 1$ & 0.22 \\
\hline & + & $2 \cdot 6$ & 0.7 & -0.02 & $4 \cdot 3$ & 0.82 \\
\hline \multirow{2}{*}{$\begin{array}{l}\text { Crude protein }(\mathrm{N} \times 6.25) \\
(\mathrm{g} / \mathrm{d})\end{array}$} & - & $172 \cdot 4$ & $21 \cdot 8$ & 0.79 & $15 \cdot 7$ & 0.98 \\
\hline & + & $189 \cdot 1$ & $23 \cdot 3$ & 0.82 & $24 \cdot 2$ & 0.99 \\
\hline \multirow[t]{2}{*}{ Lysine } & - & 0.700 & 0.033 & $0 \cdot 10+$ & $3 \cdot 5$ & $0 \cdot 76$ \\
\hline & + & 0.819 & 0.013 & $0.04+$ & $4 \cdot 6$ & 0.84 \\
\hline \multirow[t]{2}{*}{ Methionine } & - & 0.709 & 0.016 & $0.02+$ & 0.8 & 0.15 \\
\hline & + & 0.842 & 0.009 & $-0.02+$ & 1.9 & 0.47 \\
\hline \multirow[t]{2}{*}{ Cystine } & - & 0.826 & 0.006 & $0.00 \dagger$ & 0.3 & 0.02 \\
\hline & + & 0.867 & 0.006 & $0.00 \dagger$ & 0.4 & 0.04 \\
\hline \multirow[t]{2}{*}{ Threonine } & - & 0.683 & 0.023 & $0-07 \dagger$ & $2 \cdot 8$ & 0.66 \\
\hline & + & 0.826 & 0.006 & $0.01 \dagger$ & $2 \cdot 2$ & 0.55 \\
\hline
\end{tabular}

Significance of regression coefficient: $P<0.05$ if $t>2.78, P<0.01$ if $t>4.60, P<0.001$ if $t>8.61$. $\dagger b \times 100$.

Infusion of lysine (Table 4) improved the apparent digestibility of crude protein, crude fibre, gross energy and lysine (dietary + infused), when antibiotics were not added to the diet. When antibiotics were included in the diet infusion of lysine had no influence on the digestibility of gross energy, but the digestibility of crude protein was depressed. Despite the fact that the diet was very deficient in lysine $(6.3 \mathrm{~g} / \mathrm{d})$ infusion of up to $16 \mathrm{~g}$ lysine $/ \mathrm{d}$ had only a slight positive effect on $\mathrm{N}$ balance.

Infused methionine (Table 5) had only a slight but positive influence on the digestibility of the nutrients, except for a small negative response for crude protein when antibiotics were added to the diet. Infusion of up to $17 \mathrm{~g}$ methionine/ $\mathrm{d}$ had no influence on $\mathrm{N}$ balance despite the fact that the diet was deficient in methionine $(4 \cdot 2 \mathrm{~g} / \mathrm{d})$.

The influence of crude protein infusion (Table 6) on the digestibilities of the nutrients was small but positive in most instances, which demonstrates the large digestive capacity of the caecum-colon. Crude protein infused into the caecum was digested almost as well as if it had been given orally. The influence on $\mathbf{N}$ balance was slight but positive.

Caecal infusion of maizi: starch (Table 7) tended to depress the digestibilities of the nutrients except for gross energy. The digestibility of the infused maize starch DM was on average 0.89 , which is $0.08-0.09$ lower than would be expected if it were given orally. There was almost no effect on $\mathrm{N}$ balance, and urinary $\mathrm{N}$ excretion tended to be decreased by infusion of maize starch.

The infused potato starch had a small depressive effect (Table 8) on the digestibilities of the nutrients, as had maize starch, but the depressive effect on the digestibility of crude 
Table 7. The influence of infused maize starch on the digestibility of nutrients and nitrogen balance

\begin{tabular}{|c|c|c|c|c|c|c|}
\hline & \multirow[b]{2}{*}{ Antibiotics } & \multirow[b]{2}{*}{ Mean } & \multirow[b]{2}{*}{ SEM } & \multicolumn{3}{|c|}{$\begin{array}{l}\text { Regression of nutrient digestibility } \\
\text { and } \mathrm{N} \text { balance } v . \mathrm{g} \text { maize } \\
\text { starch dry matter infused }\end{array}$} \\
\hline & & & & $b$ & $t^{*}$ & $r^{2}$ \\
\hline \multirow[t]{2}{*}{ Crude protein $(\mathrm{N} \times 6 \cdot 25)$} & - & 0.802 & 0.013 & $-0.02 \dagger$ & 1.5 & 0.37 \\
\hline & + & 0.843 & 0.010 & $-0.02 \dagger$ & 4.6 & 0.88 \\
\hline \multirow[t]{2}{*}{ Crude fat } & - & 0.564 & 0.016 & $0.00 \dagger$ & 0.0 & 0.00 \\
\hline & + & 0.581 & 0.018 & $-0.04 \dagger$ & $17 \cdot 4$ & 0.99 \\
\hline \multirow[t]{2}{*}{ Crude fibre } & - & $0 \cdot 127$ & 0.027 & $-0.00 \dagger$ & 0.1 & 0.00 \\
\hline & + & -0.119 & 0.016 & $-0.03 t$ & $3 \cdot 2$ & 0.77 \\
\hline \multirow[t]{2}{*}{ Gross energy } & - & 0.813 & 0.016 & $0.00 \dagger$ & 0.9 & 0.16 \\
\hline & + & 0.789 & 0.001 & $0.00 \dagger$ & 0.2 & 0.02 \\
\hline \multirow{2}{*}{ Urinary $N(g / d)$} & - & $23 \cdot 4$ & 2.0 & -0.02 & $1 \cdot 2$ & 0.25 \\
\hline & + & 28.5 & $2 \cdot 1$ & -0.01 & 0.5 & 0.07 \\
\hline \multirow[t]{2}{*}{$N$ balance $(g / d)$} & - & 9.6 & $2 \cdot 1$ & 0.01 & 0.7 & 0.10 \\
\hline & + & 6.2 & $2 \cdot 1$ & 0.00 & 0.1 & 0.01 \\
\hline \multirow[t]{2}{*}{ DM (maize starch) (g/d) } & - & $1 \cdot 208$ & $48 \cdot 5$ & 0.93 & 11.4 & 0.97 \\
\hline & + & $1 \cdot 138$ & $40 \cdot 7$ & 0.84 & $48 \cdot 5$ & 1.00 \\
\hline \multirow[t]{2}{*}{ Lysine } & - & 0.748 & 0.021 & $-0.02 \dagger$ & $1 \cdot 3$ & 0.28 \\
\hline & + & 0.853 & 0.011 & $-0.02 \dagger$ & $7 \cdot 4$ & 0.95 \\
\hline \multirow[t]{2}{*}{ Methionine } & - & 0.743 & 0.023 & $-0.03 \dagger$ & 1.5 & 0.37 \\
\hline & + & 0.882 & 0.009 & $-0.02 \dagger$ & 8.2 & 0.96 \\
\hline \multirow[t]{2}{*}{ Cystine } & - & 0.850 & 0.009 & $-0.01 \dagger$ & 1.4 & 0.33 \\
\hline & + & 0.862 & 0.007 & $-0.01 \dagger$ & $4 \cdot 4$ & 0.86 \\
\hline \multirow{2}{*}{ Threonine } & - & 0.749 & $0-018$ & $-0.02 \dagger$ & $1 \cdot 3$ & 0.29 \\
\hline & + & 0.867 & 0.010 & $-0.02 \dagger$ & 7.2 & 0.94 \\
\hline
\end{tabular}

* Significance of regression coefficient. $P<0.05$ if $t>2.78, P<0.01$ if $t>4.60, P<0.001$ if $t>8.61$. $+b \times 100$.

fibre was much more pronounced. The digestibility of the infused potato starch DM was on average 0.84 which is a 'normal' value for dietary potato starch (Just, Jørgensen \& Fernández, 1980). Urinary $\mathrm{N}$ excretion was depressed slightly by the infusion of potato starch.

Increasing amounts of a complete balanced diet infused into the caecum had only a very small depressive effect on the digestibilities of the nutrients (Table 9). Addition of antibiotics improved the digestibilities of crude protein, crude fat and amino acids, increased $\mathbf{N}$ excretion in urine and depressed $\mathbf{N}$ balance and the digestibilities of crude fibre and energy, although none of these responses were significant.

\section{DISCUSSION}

To determine the influence of water infusion into the caecum on the digestibilities of nutrients a preliminary trial was performed in which 31 water/d was infused alone. In this trial no effects on the digestibilities of the nutrients could be detected with a complete balanced diet (Just et al. 1979).

It is questionable whether antibiotics given orally or infused into the caecum exert the same effect on digestibility and $\mathrm{N}$ balance. According to Zebrowska \& Pastuszewska (1975) neomycin added to the diet and infused into the caecum had identical effects. The application of neomycin depressed the digestibilities of crude protein and amino acids and also $\mathbf{N}$ balance in the present study. 
Table 8. The influence of infused potato starch on the digestibility of nutrients and nitrogen balance

\begin{tabular}{|c|c|c|c|c|c|c|}
\hline & \multirow[b]{2}{*}{ Antibiotics } & \multirow[b]{2}{*}{ Mean } & \multirow[b]{2}{*}{ SEM } & \multicolumn{3}{|c|}{$\begin{array}{l}\text { Regression of nutrient digestibility } \\
\text { and } N \text { balance } v . g \text { potato } \\
\text { starch dry matter infused }\end{array}$} \\
\hline & & & & $b$ & $t^{*}$ & $r^{2}$ \\
\hline \multirow[t]{2}{*}{ Crude protein $(\mathrm{N} \times 6.25)$} & - & 0.831 & 0.018 & $-0.02 \dagger$ & $1 \cdot 7$ & 0.41 \\
\hline & + & 0.844 & 0.008 & $0.01 \dagger$ & $2 \cdot 4$ & 0.58 \\
\hline \multirow[t]{2}{*}{ Crude fat } & - & 0.554 & 0.032 & $-0.01 \dagger$ & $0 \cdot 2$ & 0.01 \\
\hline & + & 0.596 & 0.019 & $-0.02 \dagger$ & 1.6 & 0.39 \\
\hline \multirow{2}{*}{ Crude fibre } & - & $0 \cdot 151$ & 0.059 & $-0.09 \dagger$ & $2 \cdot 0$ & 0.51 \\
\hline & + & -0.022 & 0.043 & $-0.07 \dagger$ & $2 \cdot 6$ & 0.63 \\
\hline \multirow{2}{*}{ Gross energy } & - & 0.819 & 0.010 & $-0.00 \dagger$ & 0.5 & 0.05 \\
\hline & + & 0.788 & 0.005 & $0.00 \dagger$ & 0.8 & 0.13 \\
\hline \multirow[t]{2}{*}{ Urinary $N(g / d)$} & - & $25 \cdot 1$ & $1 \cdot 7$ & -0.02 & 1.8 & 0.44 \\
\hline & + & $27 \cdot 3$ & $1 \cdot 2$ & -0.02 & 1.9 & 0.46 \\
\hline \multirow{2}{*}{$N$ balance $(g / d)$} & - & $8 \cdot 5$ & 1.7 & 0.01 & 0.9 & $0 \cdot 16$ \\
\hline & + & $6 \cdot 7$ & 1.4 & 0.02 & 2.5 & 0.61 \\
\hline \multirow{2}{*}{ DM (potato starch) (g/d) } & - & 1192 & $39 \cdot 6$ & 0.78 & $5 \cdot 4$ & 0.88 \\
\hline & + & 1164 & $43 \cdot 7$ & 0.89 & 17.6 & 0.99 \\
\hline \multirow{2}{*}{ Lysine } & - & 0.808 & 0.021 & $-0.03 \dagger$ & 1.5 & 0.36 \\
\hline & + & 0.854 & 0.008 & $0.01 t$ & $2 \cdot 2$ & 0.54 \\
\hline Methionine & - & 0.806 & 0.022 & $-0.03 \dagger$ & $1 \cdot 3$ & $\begin{array}{l}0.30 \\
0.62\end{array}$ \\
\hline \multirow{2}{*}{ Cystine } & 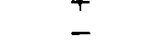 & 0.879 & $\begin{array}{l}0.007 \\
0.009\end{array}$ & $\begin{array}{r}0.01 T \\
-0.01 \dagger\end{array}$ & $\begin{array}{l}2.3 \\
1.0\end{array}$ & $\begin{array}{l}0.02 \\
0.21\end{array}$ \\
\hline & + & 0.865 & 0.004 & $0.00 \dagger$ & 1.2 & 0.25 \\
\hline \multirow[t]{2}{*}{ Threonine } & - & 0.801 & 0.020 & $-0.03 \dagger$ & 1.5 & 0.35 \\
\hline & + & 0.856 & 0.007 & $0.01 t$ & $2 \cdot 4$ & 0.60 \\
\hline
\end{tabular}

* Significance of regression coefficient. $P<0.05$ if $t>2.78, P<0.01$ if $t>4.60, P<0.001$ if $t>8.61$. $+b \times 100$.

The results of Just (1980a), Just, Sauer, Bech-Andersen et al. (1980) and Just, Sauer \& Jørgensen (1980) are in accordance with the present results showing that the addition of antibiotics to the diets increases the over-all digestibilities of crude protein and amino acids. However, their work showed that this was due to increased absorption from the small intestine. Therefore the results obtained in the present investigation might have been different if the antibiotics had been infused into the caecum instead of being included in the diets.

As indicated by Kidder \&: Manners (1978) most workers have found the value of the $\mathbf{N}$ absorbed in the hind gut for protein synthesis in the pig to be very low or negligible, which is in accordance with the results of the present investigation. The common explanation for this is that protein or amino acids entering the hind gut are converted to ammonia or amines or both, which are absorbed but cannot be used for protein synthesis (Michel, 1966; Fauconneau \& Michel, 197C ; Zebrowska, 1973, 1975; Mason et al. 1976; Sauer, 1976; Just, $1980 a$; Just, Sauer, Bech-A ndersen et al. 1980; Just, Sauer \& Jørgensen, 1980).

However, there was evidence in the present experiment that even if free lysine remains intact during passage through the caecum-colon, it is very poorly absorbed. For instance pig no. 6 (Table 4) in addition to $6 \mathrm{~g}$ antibiotics was given $6.3 \mathrm{~g}$ dietary lysine and $15.5 \mathrm{~g}$ lysine was infused into the caecum, giving $21.8 \mathrm{~g}$ lysine in total. A total of 12.7 lysine was digested and $9.1 \mathrm{~g}$ lysine was excreted in the faeces. Of the $9.1 \mathrm{~g}$ lysine excreted with the faeces at least $2.8 \mathrm{~g}(9 \cdot 1-6 \cdot 3)$ and probably approximately $7.8 \mathrm{~g}(9 \cdot 1-6.3 \times 0.2)$ originates from the infused free lysine. 
Table 9. The influence of infused complete balanced diet on the digestibility of nutrients and nitrogen balance

\begin{tabular}{|c|c|c|c|c|c|c|}
\hline & \multirow[b]{2}{*}{ Antibiotics } & \multirow[b]{2}{*}{ Mean } & \multirow[b]{2}{*}{ SEM } & \multicolumn{3}{|c|}{$\begin{array}{l}\text { Regression of nutrient digestibility } \\
\text { and } \mathrm{N} \text { balance } v \text {. } \mathrm{g} \text { diet dry matter infused }\end{array}$} \\
\hline & & & & $b$ & $t^{*}$ & $r^{2}$ \\
\hline \multirow[t]{2}{*}{ Crude protein $(\mathrm{N} \times 6.25)$} & - & 0.854 & 0.012 & $-0.01 \dagger$ & 1.7 & 0.41 \\
\hline & + & 0.869 & 0.003 & $-0.00 \dagger$ & $2 \cdot 3$ & 0.56 \\
\hline \multirow{2}{*}{ Crude fat } & - & 0.536 & 0.019 & $-0.03 \dagger$ & 2.8 & 0.66 \\
\hline & + & 0.541 & 0.020 & $-0.02 \dagger$ & 1.7 & 0.43 \\
\hline \multirow[t]{2}{*}{ Crude fibre } & - & 0.201 & 0.047 & $-0.02 \dagger$ & 0.5 & 0.05 \\
\hline & + & 0.027 & 0.029 & $0.01 \dagger$ & 0.2 & 0.01 \\
\hline \multirow{2}{*}{ Gross energy } & - & 0.819 & 0.008 & $-0.00 \dagger$ & 0.2 & 0.01 \\
\hline & + & 0.799 & 0.006 & $0.00 \dagger$ & 0.7 & $0 \cdot 11$ \\
\hline \multirow{2}{*}{ Urinary $\mathbf{N}$} & - & $33 \cdot 3$ & 1.9 & 0.00 & 0.0 & 0.00 \\
\hline & + & 39.9 & 1.8 & -0.02 & $1 \cdot 0$ & 0.19 \\
\hline \multirow[t]{2}{*}{$\mathrm{N}$ balance $(\mathrm{g} / \mathrm{d})$} & - & 4.4 & $2 \cdot 2$ & 0.01 & 0.7 & $0 \cdot 10$ \\
\hline & + & -1.5 & $2 \cdot 4$ & 0.03 & $2 \cdot 2$ & 0.55 \\
\hline \multirow[t]{2}{*}{ DM (infused diet) (g/d) } & - & 1194 & 45.5 & 0.82 & 7.3 & 0.93 \\
\hline & + & 1159 & $45 \cdot 5$ & 0.86 & 11.6 & 0.97 \\
\hline \multirow[t]{2}{*}{ Lysine } & - & 0.860 & 0.017 & $-0.02 \dagger$ & 1.7 & 0.42 \\
\hline & + & 0.889 & 0.002 & $-0.00 \dagger$ & 1.2 & 0.27 \\
\hline \multirow[t]{2}{*}{ Methionine } & - & 0.847 & 0.018 & $-0.02 \dagger$ & 1.5 & 0.37 \\
\hline & + & 0.896 & 0.004 & $-0.00 \dagger$ & 1.4 & 0.33 \\
\hline \multirow{2}{*}{ Cystine } & - & 0.881 & 0.008 & $-0.01 \dagger$ & 1.0 & 0.20 \\
\hline & + & 0.882 & 0.002 & $0.00 \dagger$ & 0.4 & 0.03 \\
\hline \multirow{2}{*}{ Threonine } & - & 0.844 & 0.016 & $-0.02+$ & $2 \cdot 0$ & 0.50 \\
\hline & + & 0.890 & 0.004 & $-0.01 \dagger$ & 1.9 & 0.46 \\
\hline
\end{tabular}

* Significance of regression coefficient. $P<0.05$ if $t>2.78, P<0.01$ if $t>4.60, P<0.001$ if $t>8.61$

$+b \times 100$.

However, there is no doubt that considerable fermentation takes place in the hind gut (Just \& Mason, 1974; Mason et al. 1976; Wolstrup et al. 1979; Just, 1980 a, b; Just, Andersen \& Jørgensen, 1980; Just, Sauer, Bech-Andersen et al. 1980; Just, Sauer \& Jørgensen, 1980; Sauer et al. 1980). The decrease in the digestibilities of crude fibre, $\mathrm{N}$-free extract and gross energy by application of antibiotics in the present investigation is also an indirect indication of a depressed microbial activity. However, it is surprising that the cacecum-colon can digest infused nutrients almost as well as if the nutrients were administered orally, both with and without dietary supplements of antibiotics. The positive effect of infused lysine on the digestibilities of crude protein, crude fibre and gross energy when antibiotics were not added to the diets (Table 4) is also an indication of increased microbial activity which in turn indicates that the basal diet might not have completely met the requirement of the microbes for lysine. However, infusion of crude protein (Table 6) had no influence on the digestibilities of crude fibre and gross energy as was anticipated because the diet was very deficient in protein (Table 3).

In the trials with methionine, $\mathrm{N}$ balance was higher than in any of the other trials, despite the fact that the diet was considered to be deficient in methionine, which suggests that the methionine requirement is somewhat lower than anticipated according to the current standards (Andersen \& Just, 1979).

Concerning the high digestibility of infused dietary DM (Table 9), it might be assumed that the nutritive value corresponds to the digestibility, but the investigations of Just (1980b) show that the value of a diet decreases with the proportion absorbed from the caecum-colon. 
Compared to the results obtained by Just \& Mason (1974), Whittemore et al. (1975), Mason et al. (1976) and Livingstone et al. (1977) the response to the starch source was small (Tables 7,8 ) and the effect of infused potato starch in particular was smaller than expected. This apparent discrepancy is probably due to the method of feeding i.e. orally or infusion into the caecum.

\section{REFERENCES}

Andersen, P. E. \& Just, A. (1979). Det kgl. danske Landhusholdningsselskab. Copenhagen.

Barr, A. J., Goodnight, H. H., Sall, J. P., Blair, W. P. \& Chilko, D. M. (1979). SAS User's Guide. SAS Institute INC., Raleigh, North Carolina.

Bech-Andersen, S. (1979). J. Chromat. 179, 227.

Combe, E., Penot, E., Charlier, H. \& Saccuet, E. (1965). Ann. Biol. Anim. Biochim. Biophys. $5,183$.

Dammers, J. (1964). Verteringsstudies bij het varken. Faktoren van invloed op de vertering der voeder-componenten en de verteerbaarheid der aminozuren. PhD Thesis. Leuven. Instituut voor Veevoedingsonderzoek, 'Hoorn'.

Eggum, B. O. (1968). Acta Agric. scand. 18, 127.

Eggum, B. O. (1972). Z. Tierphysiol. Tierernähr. Futtermittelk. 30, 172.

Eggum, B. O., Fekadu, M., Wols rup, J., Sauer, W. C. \& Just, A. (1979). J. Sci. Fd Agric. $30,177$.

Fauconneau, G. \& Michel, M. C. (1970). In Mammalian Protein Metabolism, vol. 4, pp. 481-522. [H. N. Munroe, editor]. New York: Academic Press.

Hodgon, E. S. (1977). Protein dige stion in the large intestine of the pig. MSc Thesis. University of Guelph, Canada.

Jakobsen, P. E. \& Weidner, K. (1973). In Chemistry of Feedstuffs and Animals, Compendium 1, pp. 14-55. Veterinary Faculty for FAO Fcllows, Royal Veterinary and Agricultural University of Copenhagen.

Just, A. (1980a). In Current Consepts of Digestion and Absorption in Pigs. no. 3, p. 66 [A. G. Low and I. G. Partridge, editors]. Tech. Bull. iVat. Inst. Res. Dairying.

Just, A. (1980 b). Proc. 8th Symp. Energy Metabolism of Farm Animals. Publs Eur. Ass. Anim. Prod. no. 26, p. 27.

Just, A., Andersen, J. O. \& Jørgensen, H. (1980). Z. Tierphysiol. Tierernähr. Futtermittelk. 44, 82.

Just, A., Jorgensen, H. \& Fernández, J. (1979). 30th A. Mtg. Eur. Ass. Anim. Prod., Harrogate.

Just, A., Jorgensen, H. \& Fernández, J. (1980). The digestibility, ME and NE content of individual feedstuffs for pigs. 4th edition. Copenhagen: National Institute of Animal Science.

Just, A. \& Mason, V. C. (1974). Proc. 6th Symp. Energy Metabolism of Farm Animals. Publs Eur. Ass. Anim. Prod. no. 14, p. 193.

Just, A., Sauer, W. C., Bech-Andtrsen, S., Jørgensen, H. H. \& Eggum, B. O. (1980). Z. Tierphysiol. Tierernähr. Futtermittelk. 43, 83.

Just, A., Sauer, W. C. \& Jørgensen, H. H. (1980). Publs Eur. Ass. Anim. Prod. no. 27, p. 215.

Kidder, D. E. \& Manners, M. J. (1978). Digestion in the Pig. Scientechnica. Bristol: Kingston Press.

Livingstone, R. M., Atkinson, T., Baird, B. \& Crofts, R. M. J. (1977). Abstr. Communs 36, 58a.

Mason, V. C., Just, A. \& Bech-Andersen, S. (1976). Z. Tierphysiol. Tierernähr. Futtermittelk. $36,310$.

Michel, M. C. (1966). Priv. coll. Soc. org. biol. Chem., Paris, 6, 307.

Salter, D. N. \& Coates, M. E. (1970).The influence of gut micro-organisms on utilization of dietary protein. Proc. VIIIth int. Congr. Nutr. Prague. p. 425.

Salter, D. N. \& Coates, M. E. (.971). Br. J. Nutr. 26, 55.

Salter, D. N., Coates, M. E. \& Hewitt, D. (1974). Br. J. Nutr. 31, 307.

Sauer, W. C. (1976). Factors affecting amino acid availabilities for cereal grains and their components for growing monogastric animals. PhD Thesis, University of Manitoba, Canada.

Sauer, W. C., Just A., Jørgenser, H. H., Fekadu, M. \& Eggum, B. O. (1980). Acta Agric. scand. $30,449$.

Weidner, K. \& Eggum, B. O. (1766). Acta Agric. scand. 16, 115.

Whittemore, C. T., Taylor, A. C., Moffat, I. W. \& Scott, A. (1975). J. Sci. Fd Agric. $26,255$.

Wolstrup, J., Jensen, K. \& Just, A. (1979). Ann. Rech. Vet. 10, 283.

Zebrowska, T. (1973). Roczn. Nauk. Rol. B95, 85.

Zebrowska, T. (1975). Roczn. Nizuk. Rol. B97, 117.

Zebrowska, T., Buraczewska, L. \& Horaczynski, H. (1977). Vth int. Symp. Amino Acids, Budapest.

Zebrowska, T. \& Pastuszewska, B. (1975). 26th A. Mtg. Eur. Ass. Anim. Prod. Warsaw. 